Original Research

\title{
Pollution Loads and Ecological Risk Assessment of Metals and a Metalloid in the Surface Sediment of Keenjhar Lake, Pakistan
}

\author{
Uzma Imran ${ }^{1 *}$, Asmat Ullah ${ }^{1,2,3}$, Kaleemullah Shaikh ${ }^{4}$ \\ ${ }^{1}$ U.S.-Pakistan Center for Advanced Studies in Water, Mehran University of Engineering and Technology, \\ Jamshoro, Sindh, Pakistan \\ ${ }^{2}$ The Joint Graduate School of Energy and the Environment (JGSEE), King Mongkut's University of Technology \\ Thonburi, Bang Mod, Thung Khru, Bangkok, Thailand \\ ${ }^{3}$ Centre of Excellence on Energy, Technology and the Environment, Bangkok, Thailand \\ ${ }^{4}$ Faculty of Engineering, Balochistan University of Information Technology, Engineering, \\ and Management Sciences, Quetta, Balochistan, Pakistan
}

Received: 12 November 2019

Accepted: 29 January 2020

\begin{abstract}
This study aims to analyze the concentrations of heavy metals and a metalloid in the surface sediments of Keenjhar Lake, Sindh, Pakistan that pose a risk to the lake ecosystem. The concentrations and ecological risks associated with eight metals and a metalloid ( $\mathrm{As}, \mathrm{Pb}, \mathrm{Cd}, \mathrm{Cu}, \mathrm{Mn}, \mathrm{Fe}, \mathrm{Ni}, \mathrm{Hg}$, and $\mathrm{Cr}$ ) from surface sediments of the lake, was evaluated at 10 sampling locations. The overall $95^{\text {th }}$ percentile concentrations of trace elements were observed as $\mathrm{As}$ (29.1), $\mathrm{Pb}$ (7.6), $\mathrm{Cd}$ (0.68), $\mathrm{Cu}$ (9.3), Mn (56.43), Fe (352.3), Ni (10.36), and $\mathrm{Cr}$ (29.61) $\mathrm{mg} / \mathrm{kg}$. Metal wise as well as aggregated levels of contamination were studied. It was observed that all metals except $\mathrm{Hg}$ were detected in the lake sediment. Based on the geo-accumulation index and enrichment factor, $\mathrm{Cr}, \mathrm{Cu}, \mathrm{Mn}, \mathrm{Ni}$, and $\mathrm{Pb}$ showed low pollution levels, while $\mathrm{As}, \mathrm{Cd}$, and Fe showed a high degree of contamination. Based on the $95^{\text {th }}$ percentile, the average values of $\mathrm{EF}$ for $\mathrm{As}, \mathrm{Cd}$ and $\mathrm{Fe}$ were observed as $274 \%, 300 \%$ and $907 \%$ respectively. Pollution Load Index reflected metals and metalloid contamination near the warning threshold, with an average value of 0.825 . The Nemerow integrated pollution index (range 6.79-7.59, i.e., >3) and degree of contamination (range 12-24) suggested strong pollution levels. According to the findings of the ecological risk index, Cd showed high ecological risk (between 160-320) at all sampling sites, and potential ecological risk index was at moderate risk level (between 150-300) at all locations. Multivariate analysis of the metals and a metalloid classified as $\mathrm{As}, \mathrm{Cd}$, and $\mathrm{Fe}$ in one group with the remaining metals in another group show that metals of each group originate from the same source.
\end{abstract}

Keywords: sediment pollution, heavy metals and metalloid, ecological risk assessment, multivariate analysis

*e-mail: uimran.uspcasw@faculty.muet.edu.pk 


\section{Introduction}

Heavy metals and metalloids contamination in aquatic environments have received ample attention due to their toxicity, persistence, and bioaccumulation [1-5]. Heavy metals and metalloids in sediments come from both natural and anthropogenic sources. Natural sources include flow variations, rocks wearing away, and benthonic activities, etc. [6,7], while anthropogenic sources include domestic and industrial wastewater disposal, atmospheric fallout, agricultural runoff, and fertilizer overflows, etc. [8]. Recently, rapid industrial growth along with expansion and intensification of agriculture and their associated inputs (i.e. fuel, fertilizers, and pesticides) have contributed significantly to the pollution of freshwater ecosystems through the disposal of wastewater comprising heavy metals and metalloids $[9,10]$.

In water environs, heavy metals and metalloids exhibit higher deposition in sediments [10]. Once engrossed and settled down on sediments, these heavy metals and metalloids can desorb from sediments and get dissolved into the water column due to some physiochemical and biological processes [11, 12]. As such, these sediments serve as a repository $[1,13,14]$ and a prospective secondary source of pollutants in water environs, thus warning of threats for both aquatic biota and human health [15].

The presence of heavy metals and metalloids in the aquatic food chain contributes to various kinds of issues ranging from molecular alterations to deaths in native fish populations [16]. Furthermore, the presence of trace elements in benthic organisms leads to a sharp decline in the variety, growth, and reproduction rates of these organisms [13], and thus a threat to aquatic biodiversity. Therefore, it is necessary to assess the quality of the freshwater sediments, as this approach offers a substantial understanding of the trace elements' contaminations and associated threats in order to protect water environments [17]. Assessment of the metals and metalloids contamination in lake sediments, which acts as a repository of pollution, depicts the status of the lake pollution and alerts us to the necessary measures to control pollution sources for better management.

Keenjhar Lake in Pakistan is a major freshwater reservoir, supplying water mainly for drinking to Karachi, the largest city in Pakistan, and several other towns. It supplies water to industry and partly to agriculture. Besides being a freshwater reservoir, it is a Ramsar site, a wildlife habitat, a popular tourist attraction and a place where fishing is the primary source of livelihood for the people living in its surrounding areas. The quality of the lake ecosystem greatly influences the functioning and dynamics of all these aspects. It is situated close to the Indus delta and, therefore, is vulnerable to all the upstream industrial, agricultural and urban pollutants if disposed-of in streams without any treatment. Wastewater treatment in Pakistan is not a common practice, and if treatment facilities exist, they are often inefficient.

Due to untreated industrial and domestic as well as agricultural discharges into freshwater streams and ultimately into Keenjhar Lake, it was hypothesized that heavy metals and metalloids exist in the lake and the contamination of lake surface sediment provides a closer representation of the lake pollution level [10]. Therefore, this study has been conducted to determine the concentrations of selected metals and a metalloid in surface sediments of Keenjhar Lake, Pakistan, and to assess the ecological risks associated with them.

\section{Materials and Methods}

\section{Study Area and Sampling Locations}

Keenjhar Lake is one of the largest semi-natural lakes in Asia [18]. It is located at $24^{\circ} 47^{\prime} \mathrm{N}$ and $68^{\circ} 2^{\prime} \mathrm{E}$, at a distance of about $120 \mathrm{~km}$ from Karachi. It is situated in Thatta district, Sindh, Pakistan, on the right bank of the Indus River [19]. The lake is spread over an area of about $139 \mathrm{~km}^{2}$. Keenjhar Lake was recognized as a Ramsar site for migratory birds in 1976 and a wildlife sanctuary in 1977 [20, 21]. The major source of water to Keenjhar Lake is Kalari Baghar (KB) feeder canal, bringing water from the Indus the whole year and is supplemented by occasional floods from the surrounding areas [18]. It is the primary source of water for Karachi, the largest and most populous city in the country [22]. Nearly 50,000 people living in the surroundings directly rely on the lake for their living, mainly through fishing and tourism [21, 23].

In order to determine the spatial distribution of metals and a metalloid in the lake surface sediments, 10 sampling locations were selected (Fig. 1). The sampling points were selected, keeping in mind the closeness to the possibly significant contamination sources and receiving the most credible information of the entire lake. Sampling location 'S1' is the point where $\mathrm{KB}$ feeder canal water enters into the lake. Locations 'S2' and 'S3' are near large settlements from where untreated domestic wastewater is directly discharged into the lake [18]. Location ' $\mathrm{S} 4$ ' is near a mega windmill project and settlements where the inhabitants are also involved in agricultural activities. Location ' $\mathrm{S} 5$ ' is the point where Nooriabad industrial waste finds its way to the lake when it rains. Location 'S6' is near a famous tourist spot in the middle of the lake. Locations ' $\mathrm{S} 7$ ' and ' $\mathrm{S} 8$ ' are close to two other recreation points. Location ' $\mathrm{S} 9$ ' is near a village. Location 'S10' is near the lake outlet, which gives the status of the metals and metalloid deposition just before leaving the lake. 


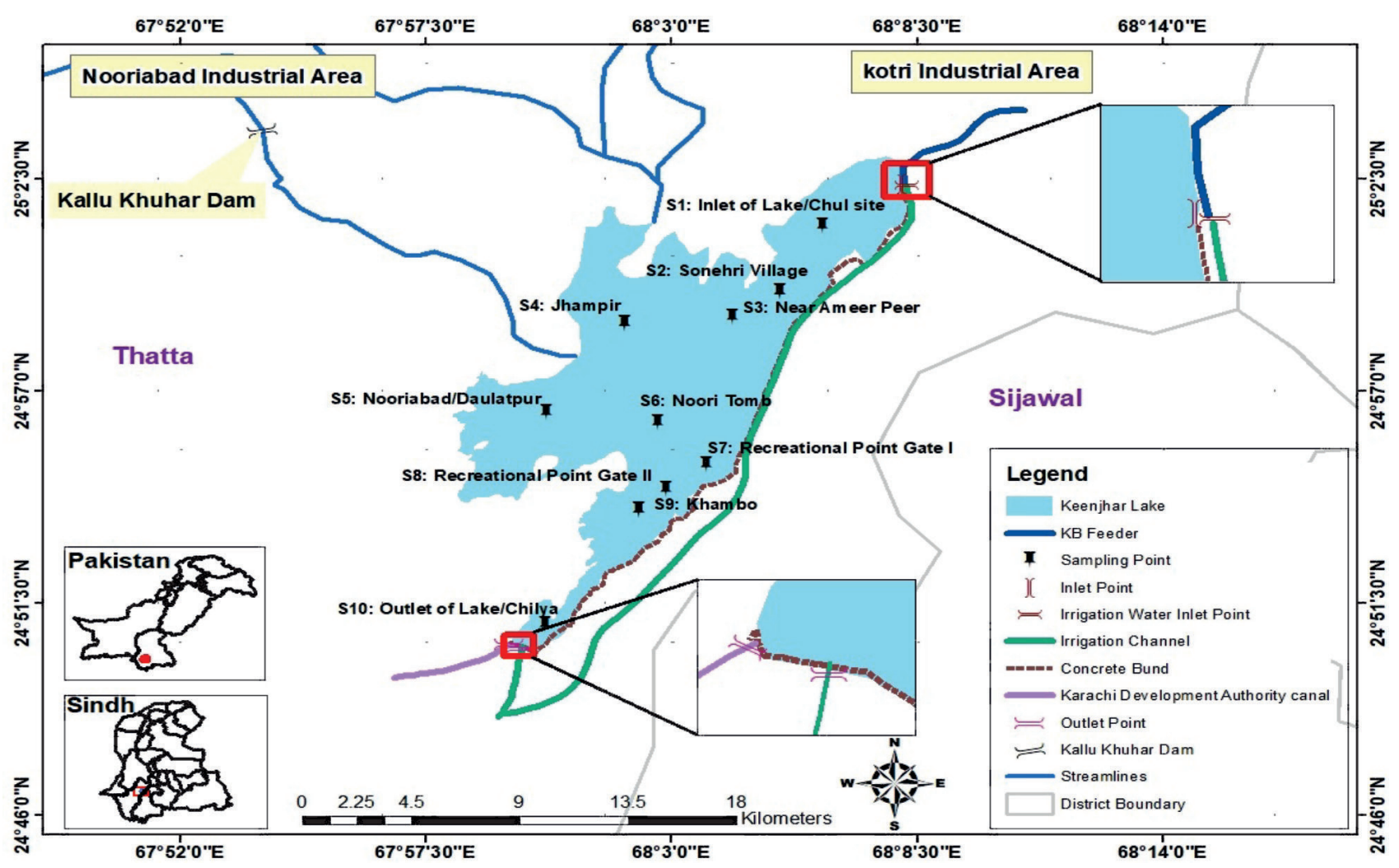

Fig. 1. The study area and the sampling sites.

\section{Sampling, Handling, Transporting, and Preserving Sediment Samples}

Sampling, handling, transporting, and preserving sediment samples was carried out according to standard methods prescribed by the Environmental Protection Agency [24]. A total of ninety (90) composite lake bed sediment samples (top layer of $0-15 \mathrm{~cm}$ ) were collected by using a submersible pump (BC-MF double channel, Pedrollo, Italy) from September 2017 to August 2018. Each composite sample comprised 3 to 5 subsamples from an area of nearly $25 \mathrm{~m}^{2}$. Polyethylene bottles (1000 $\mathrm{ml})$ soaked for 24 hours in $0.1 \%$ hydrochloric acid $(\mathrm{HCl})$ and rinsed three times with distilled water were used to collect sediment samples. To avoid any contamination, the bottles were double zip-locked separately in polythene plastic bags and properly labeled. After sampling, the samples were immediately kept in an icebox and shifted to the laboratory.

\section{Preparation of Samples}

Sediment samples were prepared by using guidelines provided by the Environmental Protection Agency [24]. Immediately after transporting samples to the laboratory, excess water present at the top of the sediment slurry was removed. The sediment slurry was poured in a china dish and dried in an oven at a temperature of about $105^{\circ} \mathrm{C}$ for 24 hours. Dried samples were crushed, homogenized and sieved through a $2 \mathrm{~mm}$ sieve and packed in pre-cleaned polyethylene bags and refrigerated until further processing [25]. For digestion, $1 \mathrm{~g}$ of sieved sediment samples were precisely weighed and placed into $250 \mathrm{ml}$ volumetric flasks and treated with $10 \mathrm{ml}$ of $1: 1 \mathrm{HNO}_{3}$ The samples were heated on a hot plate without boiling at a temperature of $95^{\circ} \mathrm{C}$ for 10 to 15 minutes. The samples were then allowed to cool for 5 minutes, and this process was repeated with the addition of $5 \mathrm{ml}$ concentrated $\mathrm{HNO}_{3}$ until brown color of the fumes stopped coming from the samples. Then the samples were placed on a hot plate without boiling for 2 hours until the samples were reduced to $5 \mathrm{ml}$, and the flasks were covered with watch glasses. After that, de-ionized water of 2-3 $\mathrm{ml}$ and $3 \mathrm{ml}$ of $30 \%$ $\mathrm{H}_{2} \mathrm{O}_{2}$ was added and placed on a hot plate for complete oxidation. Again the samples were cooled and $1 \mathrm{ml}$ of $30 \% \mathrm{H}_{2} \mathrm{O}_{2}$ was added. The samples were heated without boiling and reduced to $5 \mathrm{ml}$. Samples were diluted with de-ionized water up to $100 \mathrm{ml}$ and filtered through Whatman No. 41 and stored in pre-cleaned polyethylene bottles until analyzed.

\section{Instrumental Analyses}

The heavy metals and metalloids, including As, Fe, $\mathrm{Mn}, \mathrm{Cu}, \mathrm{Ni}, \mathrm{Cd}, \mathrm{Pb}, \mathrm{Hg}$, and $\mathrm{Cr}$, were analyzed by the 'APHA 311A' method [26] on a flame atomic absorption spectrophotometer (AAS) (A1200, Aurora Biomed, Canada). The calibration line method was adopted for the quantification of the selected trace elements [25]. 
The detection limits of the trace elements on the AAS were observed to be $0.002,0.0013,0.0019,0.0002$, $0.00001,0.0112,0.0006,0.0001$ and 0.01 milligram per liter $\left(\mathrm{mg} \mathrm{L}^{-1}\right)$ for $\mathrm{As}, \mathrm{Pb}, \mathrm{Cr}, \mathrm{Cd}, \mathrm{Cu}, \mathrm{Fe}, \mathrm{Mn}, \mathrm{Ni}$, and $\mathrm{Hg}$ respectively.

\section{Quality Control and Quality Assurance}

All the samples were analyzed under the best analytical environments as per the recommendations of equipment manufacturers. Standard operating procedures were used to provide quality control and quality assurance, including the use of high-purity chemicals and reagents to regulate contamination during preparation of sediment samples, and properly washing laboratory glassware first with tap water, then with liquid detergent, and immersed in deionized (DI) water with 5\% nitric acid for 24 hours, and finally rinsed with DI water. It was finally rinsed with acetone to avoid any risk of contamination with residual organic matter. In the end, the glasswares were kept for about 8 hours in an oven to dry at $85^{\circ} \mathrm{C}$. A stock solution was used to make new metals standards by consecutive dilutions on the day of analysis, and the dilutions were achieved only with DI water [27]. Recovery and reproducibility studies were undertaken to validate the accuracy of the methods implemented in the analysis. The certified standard reference solutions for $\mathrm{As}, \mathrm{Cd}, \mathrm{Cr}, \mathrm{Cu}, \mathrm{Fe}, \mathrm{Hg}$, $\mathrm{Mn}, \mathrm{Ni}$, and $\mathrm{Pb}$ were used. The percentage recoveries of the metals and metalloid in the standard reference material samples ranged from 92 to $100 \%$. All the measurements were made in triplicate. The accuracy of the results was verified by analyzing a few sediment samples from another independent laboratory, and the difference between the two results was observed to be maximum $\pm 2.3 \%$.

\section{Surface Sediment Contamination Level of the Lake}

The contamination level of heavy metals and metalloids in the lake surface sediments was evaluated by using various developed indices that exist in literature. These selected indices include the geoaccumulation index $\left(\mathrm{I}_{\mathrm{geo}}\right)$, enrichment factor (EF), pollution load index (PLI), Nemerow integrated pollution index $(\mathrm{Pn})$, degree of contamination $\left(\mathrm{C}_{\mathrm{d}}\right)$ and potential ecological risk index (PERI). The $\mathrm{I}_{\text {geo }}$, EF, and $\mathrm{C}_{d}$ are commonly used to find out the contamination levels caused by each element. However, PLI, Pn, and PERI assess the cumulative ecological risk caused by various elements under study [25, 28-30].

The calculations of most of these indices require background values of the elements. In this study, background concentrations used to compute these indices were taken from literature as $7.8,19,0.1,35$, 514, 35, 33 and $37.5 \mathrm{mg} / \mathrm{kg}$ for $\mathrm{As}, \mathrm{Pb}, \mathrm{Cd}, \mathrm{Cu}, \mathrm{Mn}, \mathrm{Fe}$, $\mathrm{Ni}$ and $\mathrm{Cr}$ respectively $[1,6,11,31-34]$, and were kept lower than the threshold limits [35].

\section{Geo-Accumulation Index ( $\left.I_{\text {ged }}\right)$}

The $\mathrm{I}_{\text {geo }}$ developed by Müller in 1969 [10, 36], was used to assess the pollution level in sediments through a comparison of the existing concentrations of each metal and metalloid to that of the uncontaminated or pre-industrial time. Due to the absence of pre-industrial data, global average shale [37] was adopted as the standard for reference $[38,39]$. $\mathrm{I}_{\text {geo }}$ was calculated by using Equation (1):

$$
I_{g e o}=\log _{2} \frac{C_{n}}{1.5 \times B_{n}}
$$

...where ' $\mathrm{Cn}$ ' and ' $\mathrm{Bn}$ ' are the measured and background concentrations of the elements ' $n$ ' respectively, and the factor 1.5 compensates the likely variations of the background data due to geogenic variations. The $\mathrm{I}_{\text {geo }}$ divides the contamination degree into seven categories, and the ranges of values and their interpretation are given in Table 1.

\section{Enrichment Factor (EF)}

The EF was used to assess the extent of anthropogenic metals and metalloid contamination levels in the surface sediment using Equation (2) [40]:

$$
E F=\left(\frac{C_{n}}{B_{n}}-1\right) * 100
$$

The classes into which EF is divided are given in Table 1 .

\section{Pollution Load Index (PLI)}

The PLI denotes the number of times by which the metal concentrations in the sediment exceeds the background concentrations [41] and was calculated by employing Equation (3):

$$
P L I=(C F 1 * C F 2 * C F 3 * C F 4 \ldots \ldots \ldots \ldots F n)^{1 / n}
$$

...where $\mathrm{CF}$ is the contamination factor, and it is the ratio of the concentration of individual metals or metalloids present in the studied sediment ' $\mathrm{Cn}$ ' by its background 'Bn' value as given in Equation (4):

$$
\mathrm{CF}=\frac{C_{n}}{B_{n}}
$$

If the value of PLI exceeds 1 , it reflects significant contamination [42]. However, if less than 1, then it shows no contamination.

\section{Nemerow Integrated Pollution Index (Pn)}

Pn was used to determine the pollution level in sediments using Equation (5) [40]: 
Table 1. Contamination levels as per Geo-Accumulation Index (Igeo), Contamination Factor (CF), and Enrichment Factor (EF).

\begin{tabular}{|c|c|c|c|c|c|c|c|c|}
\hline \multicolumn{3}{|c|}{ Geo-accumulation Index $\left(\mathrm{Ig}_{\text {geo }}\right)$} & \multicolumn{3}{c|}{ Contamination Factor $(\mathrm{CF})$} & \multicolumn{3}{c|}{ Enrichment Factor $(\mathrm{EF})$} \\
\hline Classes & $\mathrm{I}_{\mathrm{geo}}$ Value & Contamination level & Classes & CF Value & $\begin{array}{c}\text { Contamination } \\
\text { level }\end{array}$ & Classes & $\begin{array}{c}\text { EF } \\
\text { Value }\end{array}$ & Contamination level \\
\hline 0 & $\mathrm{I}_{\mathrm{geo}} \leq 0$ & Unpolluted & 1 & $\mathrm{CF}<1$ & Low & 1 & $\mathrm{EF}<1$ & Not contaminated \\
\hline 1 & $0<\mathrm{I}_{\mathrm{geo}}<1$ & $\begin{array}{c}\text { Unpolluted to moderately } \\
\text { polluted }\end{array}$ & 2 & $1<\mathrm{CF}<3$ & Moderate & 2 & EF $>1$ & Contaminated \\
\hline 2 & $1<\mathrm{I}_{\text {geo }}<2$ & Moderately polluted & 3 & $3<\mathrm{CF}<6$ & Considerable & - & - & - \\
\hline 3 & $2<\mathrm{I}_{\text {geo }}<3$ & Moderately to heavily polluted & 4 & $6>\mathrm{CF}$ & Very High & - & - & - \\
\hline 4 & $3<\mathrm{I}_{\text {geo }}<4$ & Heavily polluted & - & - & - & - & - & - \\
\hline 5 & $4<\mathrm{I}_{\text {geo }}<5$ & Heavily to extremely polluted & - & - & - & - & - & - \\
\hline 6 & $5>\mathrm{I}_{\text {geo }}$ & Extremely polluted & - & - & - & - & - & - \\
\hline
\end{tabular}

$$
P_{n}=\left[\frac{\left(C F_{i a v}\right)^{2}+\left(C F_{\text {imax }}\right)^{2}}{2}\right]^{1 / 2}
$$

...where ' $\mathrm{CF}_{\text {iav }}$ ' is the average value of the $\mathrm{CFs}$ while ' $\mathrm{CF}_{\text {imax }}$ ' maximum values of $\mathrm{CFs}$ in location ' $i$ ' respectively. The contamination factors of all metals and metalloids computed in Equation (4) were used to compute ' $\mathrm{CF}_{\text {iav }}$ ' and ' $\mathrm{CF}_{\text {imax }}$ '. The five classes of Pn are shown in Table 2.

\section{Degree of Contamination $\left(C_{d}\right)$}

The $C_{d}$ was determined using equation (6) [33], and it shows the aggregated value of $\mathrm{CF}$ of all metals and the metalloid under discussion:

$$
C_{d}=\sum_{i=1}^{n} C F
$$

The $\mathrm{C}_{\mathrm{d}}$ has been classified into four categories, including: category 0 (low degree of pollution: $C_{d}<6$ ); category 1 (moderate degree of pollution: $6<\mathrm{C}_{\mathrm{d}} \leq 12$ ); category 2 (considerable degree of pollution: $12<\mathrm{C}_{\mathrm{d}} \leq 24$ ); and category 3 (high degree of pollution: $C_{d}<24$ ) [43].

\section{Potential Ecological Risk Index (PERI)}

PERI has been used to determine the potential risk due to heavy metals and metalloid contamination by representing the lethalness of the specific metals and metalloids; and the sensitivity of the environment to the contaminants. PERI was calculated by using formulas (7) and (8):

$$
\begin{aligned}
\mathrm{PERI} & =\sum_{i=1}^{n} E r i \\
\mathrm{ERI} & =\operatorname{Tr} * \mathrm{CF}
\end{aligned}
$$

...where 'Eri', 'CF', and 'Tr' are the monomial ecological risk value, contamination factor, and toxic/lethal response value or factor. The ' $\mathrm{Tr}$ ' values of $\mathrm{Pb}, \mathrm{Cu}, \mathrm{Fe}$, $\mathrm{Ni}, \mathrm{Cr}, \mathrm{Mn}, \mathrm{Cd}$ and As were 5, 5 5, 2, 1,30, and 10 [33]. The ERI [43] and PERI [33, 40, 44-48] are classified into five (5) classes as shown in Table 2.

\section{Statistical Analyses}

In order to extract a small number of independent factors, principal component analysis (PCA) has been employed to identify the relationship of the metal accumulations in the sediments. Standardized principal component analysis using the Varimax rotation method has been employed to identify the variables with a high loading factor on each component. Principle components (PCs) have been selected based on Eigenvalues $>1$. Besides PCA, cluster analysis (CA) has also been employed to organize and group the metals

Table 2. Contimination levels as per Potential Ecological Risk Index (Eri and PERI) and Nemerow Integrated Pollution Index (Pn).

\begin{tabular}{|c|c|c|c|c|c|c|c|c|}
\hline \multicolumn{3}{|c|}{ Ecological Risk Index (Eri) } & \multicolumn{2}{c|}{ Potential Ecological Risk Index (PERI) } & \multicolumn{3}{c|}{ Nemerow Integrated Pollution Index (Pn) } \\
\hline Classes & Eri Value & Ecological Risk & Classes & PERI Value & Ecological Risk & Classes & Pn Value & Contamination level \\
\hline 1 & Eri $<40$ & Low & 1 & PERI $<150$ & Low & 1 & $0<$ Pn $\leq 0.7$ & Unpolluted \\
\hline 2 & $40<$ Eri $<80$ & Moderate & 2 & $150<$ PERI $<300$ & Moderate & 2 & $0.7 \leq$ Pn $\leq 1$ & Warning Limit \\
\hline 3 & $80<$ Eri $<160$ & Appreciable & 3 & $300<$ PERI $<600$ & Considerable & 3 & $1 \leq$ Pn $\leq 2$ & Low Polluted \\
\hline 4 & $160<$ Eri $<320$ & High & 4 & $600>$ PERI & Very High & 4 & $2 \leq \mathrm{Pn} \leq 3$ & Moderately Polluted \\
\hline 5 & $320>$ Eri & Serious & 5 & & & 5 & $3>$ Pn & Strongly Polluted \\
\hline
\end{tabular}


into two or more than two clusters using the hierarchal cluster analysis approach. The distances among the metals define the clusters of the metals. Pearson's pairwise correlations have been computed to determine the inter-parameter relationship, which eventually helps to illustrate the source of metals and metalloid. All these analyses have been performed using the Statistical Package for Social Science (SPSS).

\section{Results and Discussion}

\section{Metals and Metalloid Concentrations in Lake Surface Sediments}

Table 3 shows the descriptive statistics of heavy metals and metalloid in Keenjhar Lake sediments. The overall $95^{\text {th }}$ percentile concentrations and ranges of all metals and the metalloid in lake surface sediments were observed as: As 29.1 (0.41-42.30), Pb 7.6 (0.09-9.48), $\mathrm{Cd} 0.68$ (0.00-0.69), $\mathrm{Cu} 9.30$ (0.1-11.53), Fe 352.30 (155.52-362.53), Mn 56.43 (12.28-64.98), Ni 10.36
(0.00-13.36), and $\mathrm{Cr} 29.61(0.12-44.63)$ in $\mathrm{mg} / \mathrm{kg}$. Besides these metals, $\mathrm{Hg}$ was also analyzed but not detected from any sampling location and, therefore, not reported in the tables.

The mean measured concentrations of heavy metals in surface sediments of Keenjhar Lake were compared with the reported values from some important lakes in Pakistan and a few from other countries as shown in Table 4. Most of these lakes supply water to downstream cities and got contaminated due to upstream anthropogenic activities. It was observed that the concentrations of $\mathrm{Pb}, \mathrm{Cd}, \mathrm{Cu}, \mathrm{Fe}$, and $\mathrm{Mn}$ were found to be higher than the two most important lakes in Pakistan: Khanpur Lake (winter) [36] and Rawal Lake [49]. The concentration of $\mathrm{Cr}$ was found to be higher than in Rawal Lake. Both Khanpur and Rawal Lakes supply water to Islamabad (the capital city of Pakistan) and Rawalpindi [49]. The values of Cd were higher than in Sapanca Lake, Turkey [50]. However, the concentrations observed in Keenjhar Lake for $\mathrm{As}, \mathrm{Pb}$, $\mathrm{Cd}, \mathrm{Cu}, \mathrm{Fe}, \mathrm{Mn}, \mathrm{Ni}$, and $\mathrm{Cr}$ were lower than in Simly Lake [25], Khanpur Lake (summer) [36], Mangla Lake

Table 3. Descriptive statistics of heavy metals and metalloid $(\mathrm{mg} / \mathrm{kg})$ in surface sediments of Keenjhar Lake.

\begin{tabular}{|c|c|c|c|c|c|c|c|c|c|}
\hline \multirow{2}{*}{\multicolumn{2}{|c|}{ Locations }} & As & $\mathrm{Pb}$ & $\mathrm{Cd}$ & $\mathrm{Cu}$ & $\mathrm{Fe}$ & $\mathrm{Mn}$ & $\mathrm{Ni}$ & $\mathrm{Cr}$ \\
\hline & & \multicolumn{8}{|c|}{$(\mathrm{mg} / \mathrm{kg})$} \\
\hline & TEL & 5.90 & 35.00 & 0.60 & 35.70 & - & - & 18.10 & 37.30 \\
\hline \multirow{2}{*}{ Overall } & Mean & 9.52 & 4.54 & 0.31 & 3.57 & 256.32 & 34.52 & 5.25 & 10.17 \\
\hline & $95^{\text {th }}$ Percentile & 29.14 & 7.56 & 0.68 & 9.03 & 352.30 & 56.43 & 10.36 & 29.61 \\
\hline \multirow{2}{*}{ S1 } & Mean & 9.20 & 3.90 & 0.25 & 2.50 & 247.90 & 32.90 & 4.20 & 11.10 \\
\hline & $95^{\text {th }}$ Percentile & 25.17 & 6.49 & 0.68 & 6.21 & 362.24 & 63.90 & 6.33 & 25.26 \\
\hline \multirow{2}{*}{ S2 } & Mean & 11.20 & 4.20 & 0.23 & 3.40 & 246.90 & 33.80 & 6.70 & 13.00 \\
\hline & $95^{\text {th }}$ Percentile & 25.67 & 7.63 & 0.65 & 7.87 & 329.30 & 42.96 & 9.86 & 37.17 \\
\hline \multirow{2}{*}{ S3 } & Mean & 12.30 & 5.60 & 0.25 & 4.90 & 255.40 & 50.20 & 8.20 & 14.00 \\
\hline & $95^{\text {th }}$ Percentile & 26.19 & 8.22 & 0.67 & 8.82 & 352.31 & 59.26 & 10.99 & 25.61 \\
\hline \multirow{2}{*}{ S4 } & Mean & 12.00 & 4.30 & 0.28 & 4.00 & 257.20 & 43.60 & 7.40 & 10.10 \\
\hline & $95^{\text {th }}$ Percentile & 18.40 & 6.72 & 0.64 & 7.65 & 352.35 & 54.49 & 11.71 & 23.78 \\
\hline \multirow{2}{*}{ S5 } & Mean & 10.20 & 5.70 & 0.29 & 3.20 & 242.60 & 32.20 & 6.20 & 10.00 \\
\hline & $95^{\text {th }}$ Percentile & 26.79 & 8.60 & 0.67 & 6.75 & 327.81 & 43.55 & 7.86 & 28.83 \\
\hline \multirow{2}{*}{ S6 } & Mean & 6.90 & 4.60 & 0.32 & 3.70 & 245.80 & 32.40 & 5.20 & 11.70 \\
\hline & $95^{\text {th }}$ Percentile & 16.17 & 7.50 & 0.66 & 5.60 & 346.90 & 45.02 & 10.24 & 31.59 \\
\hline \multirow{2}{*}{ S7 } & Mean & 6.50 & 4.50 & 0.30 & 4.40 & 247.10 & 31.20 & 5.00 & 10.80 \\
\hline & $95^{\text {th }}$ Percentile & 17.62 & 6.59 & 0.69 & 8.36 & 327.77 & 42.16 & 9.03 & 29.14 \\
\hline \multirow{2}{*}{ S8 } & Mean & 9.30 & 4.30 & 0.30 & 3.40 & 237.40 & 27.00 & 3.70 & 9.60 \\
\hline & $95^{\text {th }}$ Percentile & 18.79 & 5.67 & 0.66 & 7.16 & 337.54 & 35.95 & 6.14 & 21.79 \\
\hline \multirow{2}{*}{ S9 } & Mean & 10.20 & 4.00 & 0.24 & 4.50 & 251.90 & 35.30 & 6.20 & 10.10 \\
\hline & $95^{\text {th }}$ Percentile & 29.38 & 5.37 & 0.63 & 8.58 & 349.54 & 44.40 & 11.07 & 19.58 \\
\hline \multirow{2}{*}{ S10 } & Mean & 6.60 & 4.00 & 0.23 & 3.00 & 238.10 & 24.90 & 4.80 & 6.50 \\
\hline & $95^{\text {th }}$ Percentile & 19.42 & 5.30 & 0.67 & 5.71 & 324.99 & 32.41 & 7.23 & 14.21 \\
\hline
\end{tabular}

$\mathrm{TEL}=$ Threshold Effect Level for Fresh Water Sediments by Environment Canada 1994.

Numbers in bold indicate mean or $95^{\text {th }}$ percentile concentration in surface sediments exceeding TEL Limits. 
Table 4. Comparison of the mean concentrations of metals and a metalloid from Keenjhar Lake with national and international reported levels.

\begin{tabular}{|c|c|c|c|c|c|c|c|c|c|}
\hline Studied Lakes & $\mathrm{As}$ & $\mathrm{Pb}$ & $\mathrm{Cd}$ & $\mathrm{Cu}$ & $\mathrm{Fe}$ & $\mathrm{Mn}$ & $\mathrm{Ni}$ & $\mathrm{Cr}$ & $\mathrm{Reference}$ \\
\hline Keenjhar Lake & 9.52 & 4.54 & 0.31 & 3.57 & 256.32 & 34.52 & 5.25 & 10.17 & Present study \\
\hline Simly Lake, Pakistan & - & 41.00 & 1.55 & 23.40 & 6122 & 647 & - & 41.00 & {$[25]$} \\
\hline Khanpur Lake, Pakistan (Summer) & - & 33.71 & 1.883 & 36.84 & 4630 & 447.5 & - & 34.66 & {$[36]$} \\
\hline Khanpur Lake, Pakistan (Winter) & - & $\mathbf{0 . 0 8 5}$ & $\mathbf{0 . 0 5 8}$ & $\mathbf{0 . 0 9 8}$ & $\mathbf{2 . 0 6 9}$ & $\mathbf{0 . 0 7 8}$ & - & 37.65 & {$[36]$} \\
\hline Rawal Lake, Pakistan & - & $\mathbf{0 . 8 6 9}$ & $\mathbf{0 . 0 4 3}$ & $\mathbf{0 . 1 6 1}$ & $\mathbf{2 1 . 5 0}$ & $\mathbf{0 . 3 8 6}$ & - & 0.309 & {$[49]$} \\
\hline Mangla Lake, Pakistan (Summer) & - & 17.20 & 1.33 & 13.40 & 3870 & 324 & - & 21.30 & {$[51]$} \\
\hline Mangla Lake, Pakistan (Winter) & - & 306.00 & 1.52 & 23.30 & 3800 & 612 & - & 42.00 & {$[51]$} \\
\hline Plateau Lake Wetland, China & 15.46 & 53.19 & 0.76 & 31.40 & - & - & 35.99 & 86.73 & {$[52]$} \\
\hline Lake Karla, Thessaly, Greece (Summer) & - & 35.00 & - & 35.20 & - & - & 158 & 285.00 & {$[53]$} \\
\hline Lake Karla, Thessaly, Greece (Winter) & - & 38.90 & - & 37.70 & - & - & 192 & 290.00 & {$[53]$} \\
\hline Lake Sapanca, Turkey & - & 15.20 & $\mathbf{0 . 2 9}$ & 26.68 & & 337.8 & 26.72 & 19.09 & {$[50]$} \\
\hline
\end{tabular}

Numbers in bold indicate the average concentration of metals and metalloids in surface sediments of national and international reported levels lower than Keenjhar Lake, while dashed cells indicate information not available.

(summer and winter) [51], Plateau Lake wetland, China [52], Karla Lake Thessaly, Greece (summer and winter)

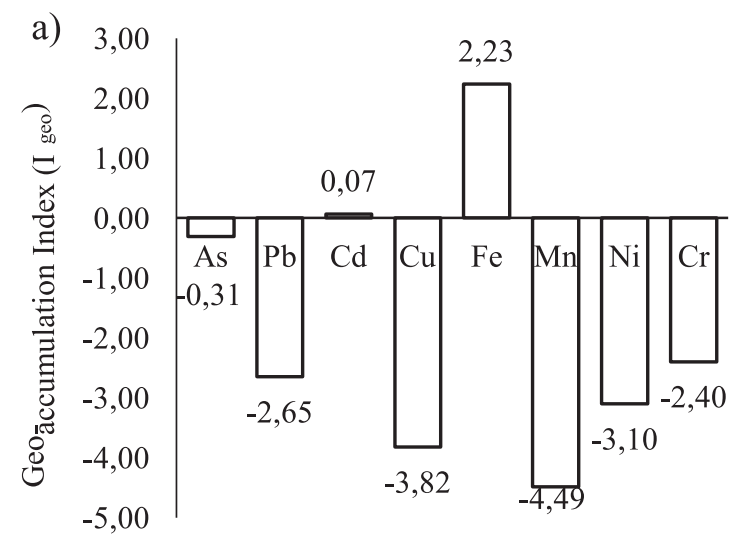

Metals and Metalloid

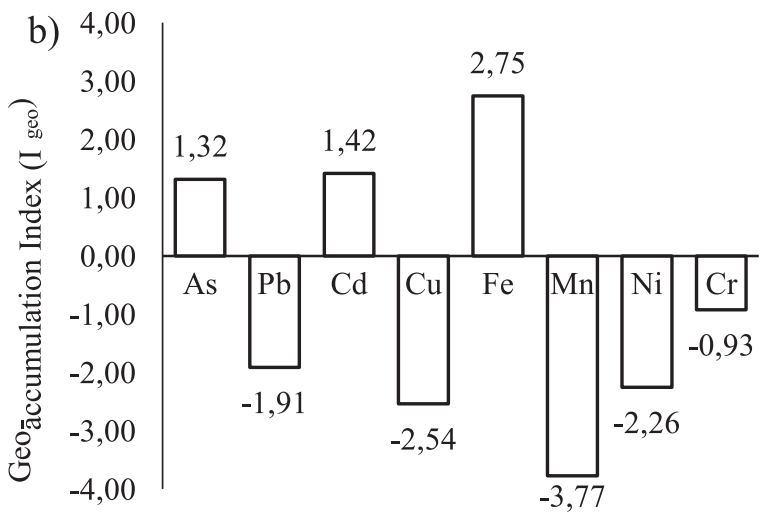

Metals and Metalloid

Fig. 2. Metal-wise Geo-Accumulation Index $\left(\mathrm{I}_{\mathrm{geo}}\right)$ scores: mean value a) and 95 percentile b).
[53] and Sapanca Lake, Turkey; with the exception of Cd higher than Sapanca Lake [50].

a)

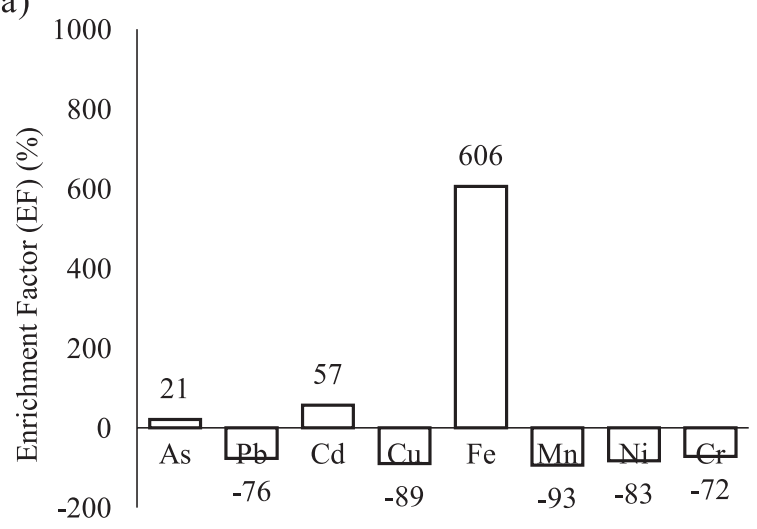

b)

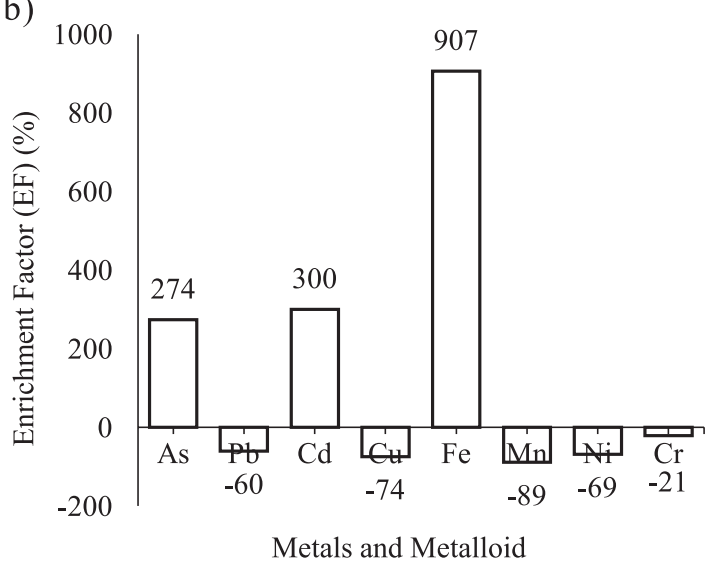

Fig. 3. The metal wise score of enrichment factor (EF) mean value a) and 95 percentile b). 
Table 5. Degree of Contamination and Pollution Load Index as per sampling locations.

\begin{tabular}{|c|c|c|c|c|c|c|c|c|c|c|}
\hline \multirow{2}{*}{ Sites } & \multicolumn{8}{|c|}{ Contamination Factor (CF) } & \multirow{2}{*}{$\mathrm{C}_{\mathrm{d}}$} & \multirow{2}{*}{ PLI } \\
\hline & As & $\mathrm{Pb}$ & $\mathrm{Mn}$ & $\mathrm{Cd}$ & $\mathrm{Cu}$ & $\mathrm{Fe}$ & $\mathrm{Ni}$ & $\mathrm{Cr}$ & & \\
\hline S1 & 3.23 & 0.34 & 0.12 & 6.80 & 0.18 & 10.35 & 0.19 & 0.67 & 21.89 & 0.83 \\
\hline S2 & 3.29 & 0.40 & 0.08 & 6.50 & 0.22 & 9.41 & 0.30 & 0.99 & 21.20 & 0.90 \\
\hline S3 & 3.36 & 0.43 & 0.12 & 6.70 & 0.25 & 10.07 & 0.33 & 0.68 & 21.94 & 0.95 \\
\hline S4 & 2.36 & 0.35 & 0.11 & 6.40 & 0.22 & 10.07 & 0.35 & 0.63 & 20.49 & 0.85 \\
\hline S5 & 3.43 & 0.45 & 0.08 & 6.70 & 0.19 & 9.37 & 0.24 & 0.77 & 21.24 & 0.86 \\
\hline S6 & 2.07 & 0.39 & 0.09 & 6.60 & 0.16 & 9.91 & 0.31 & 0.84 & 20.38 & 0.82 \\
\hline S7 & 2.26 & 0.35 & 0.08 & 6.90 & 0.24 & 9.36 & 0.27 & 0.78 & 20.24 & 0.82 \\
\hline S8 & 2.41 & 0.30 & 0.07 & 6.60 & 0.20 & 9.64 & 0.19 & 0.58 & 19.99 & 0.72 \\
\hline S9 & 3.77 & 0.28 & 0.09 & 6.30 & 0.25 & 9.99 & 0.34 & 0.52 & 21.53 & 0.84 \\
\hline $\mathrm{S} 10$ & 2.49 & 0.28 & 0.06 & 6.70 & 0.16 & 9.29 & 0.22 & 0.38 & 19.58 & 0.66 \\
\hline
\end{tabular}

To scrutinize if there is any influence of human activity on the variation of concentrations of metals specific to sampling locations, the orders of the concentrations of metals were compared across locations. It was observed that the orders of the concentrations vary except for $\mathrm{Fe}, \mathrm{Mn}$ and $\mathrm{Cd}$. Spatial distribution of selected metals and a metalloid based on the $95^{\text {th }}$ percentile concentration were following the orders at each site as: $\mathrm{S} 1 \quad(\mathrm{Fe}>\mathrm{Mn}>\mathrm{Cr}>\mathrm{As}>\mathrm{Pb}>\mathrm{Ni}>\mathrm{Cu}>\mathrm{Cd})$; at sites $\mathrm{S} 2, \mathrm{~S} 4$ and $\mathrm{S} 7(\mathrm{Fe}>\mathrm{Mn}>\mathrm{Cr}>\mathrm{As}>\mathrm{Ni}>\mathrm{Pb}>\mathrm{Cu}>\mathrm{Cd})$; sites $\mathrm{S} 3, \mathrm{~S} 9$ and $\mathrm{S} 10(\mathrm{Fe}>\mathrm{Mn}>\mathrm{As}>\mathrm{Cr}>\mathrm{Ni}>\mathrm{Cu}>\mathrm{Pb}>\mathrm{Cd})$; sites $\mathrm{S} 5$ and $\mathrm{S} 6(\mathrm{Fe}>\mathrm{Mn}>\mathrm{Cr}>\mathrm{As}>\mathrm{Ni}>\mathrm{Pb}>\mathrm{Cu}>\mathrm{Cd})$; and site $\mathrm{S} 8(\mathrm{Fe}>\mathrm{Mn}>\mathrm{Cr}>\mathrm{As}>\mathrm{Cu}>\mathrm{Ni}>\mathrm{Pb}>\mathrm{Cd})$.

\section{Ecological Risk Assessment \\ Geo-Accumulation Index ( $\left.I_{\text {geo }}\right)$}

In order to investigate the average and maximum potential pollution levels, the $\mathrm{I}_{\text {geo }}$ of metals and metalloids were estimated based on the average as well as $95^{\text {th }}$ percentile values. Both approaches were used considering the spread of the data, since reporting based on average values alone may underestimate the potential environmental hazards and similarly, the $95^{\text {th }}$ percentile may overestimate. Among the seven categories of $\mathrm{I}_{\text {geo, }}$ with category 0 representing unpolluted to category 6 indicating extreme pollution, results of this study show that $\mathrm{I}_{\text {geo }}$ of $\mathrm{Pb}, \mathrm{Mn}, \mathrm{Cu}, \mathrm{Ni}$, and $\mathrm{Cr}$ were found less than zero as shown in Fig. 2, indicating unpolluted concerning these metals. Concerning As, the lake is unpolluted (based on average values; Fig. 2a) and moderately polluted (based on $95^{\text {th }}$ percentile; Fig. 2b). The values of $\mathrm{I}_{\text {geo }}$ of $\mathrm{Cd}$ indicate moderate pollution, while Fe indicates moderate to heavy pollution. Overall, Keenjhar Lake was observed to be polluted by Fe, As, and $\mathrm{Cd}$, and these metals might be contributed through both geogenic and anthropogenic sources into lake sediments.

\section{Enrichment Factor (EF)}

EF is used to evaluate the influence of anthropogenic input of single metal and metalloid in the lake surface sediment. The $\mathrm{EF}$ values of $\mathrm{As}$, Fe, and $\mathrm{Cd}$ were

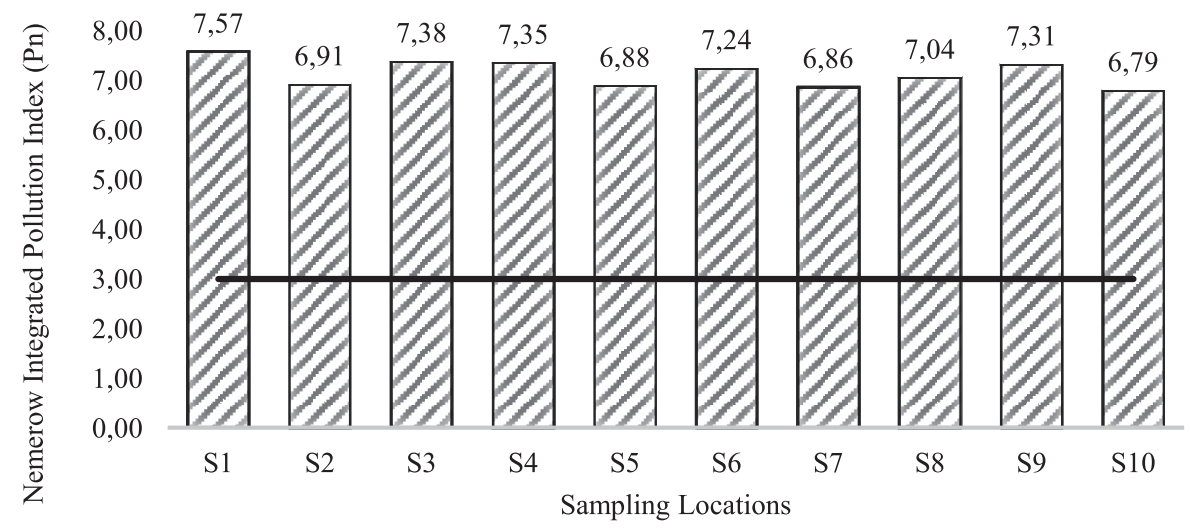

Fig. 4. Sampling location-wise scores of Nemerow Integrated Pollution Index (Pn). 
Table 6. Ecological Risk Index (ERI) of metals and a metalloid at different sites.

\begin{tabular}{|c|c|c|c|c|c|c|c|c|}
\hline Sites & $\mathrm{As}$ & $\mathrm{Pb}$ & $\mathrm{Mn}$ & $\mathrm{Cd}$ & $\mathrm{Cu}$ & $\mathrm{Ni}$ & $\mathrm{Cr}$ & PERI \\
\hline $\mathrm{S} 1$ & 32.27 & 1.71 & 0.12 & 204.00 & 0.89 & 0.96 & 1.35 & 241.30 \\
\hline $\mathrm{S} 2$ & 32.91 & 2.01 & 0.08 & 195.00 & 1.12 & 1.49 & 1.98 & 234.59 \\
\hline $\mathrm{S} 3$ & 33.58 & 2.16 & 0.12 & 201.00 & 1.26 & 1.67 & 1.37 & 241.16 \\
\hline $\mathrm{S} 4$ & 23.59 & 1.77 & 0.11 & 192.00 & 1.09 & 1.77 & 1.27 & 221.60 \\
\hline $\mathrm{S} 5$ & 34.35 & 2.26 & 0.08 & 201.00 & 0.96 & 1.19 & 1.54 & 241.38 \\
\hline $\mathrm{S} 6$ & 20.73 & 1.97 & 0.09 & 198.00 & 0.80 & 1.55 & 1.69 & 224.83 \\
\hline $\mathrm{S} 7$ & 22.59 & 1.73 & 0.08 & 207.00 & 1.19 & 1.37 & 1.55 & 235.51 \\
\hline $\mathrm{S} 8$ & 24.09 & 1.49 & 0.07 & 198.00 & 1.02 & 0.93 & 1.16 & 226.76 \\
\hline $\mathrm{S} 9$ & 37.67 & 1.41 & 0.09 & 189.00 & 1.23 & 1.68 & 1.04 & 232.12 \\
\hline $\mathrm{S} 10$ & 24.90 & 1.39 & 0.06 & 201.00 & 0.82 & 1.10 & 0.76 & 230.03 \\
\hline
\end{tabular}

Threshold limit for ERI $=40$

higher than one, indicating that these metals in surface sediments belong to both geogenic and anthropogenic sources. Nevertheless, the values of $\mathrm{EF}$ of $\mathrm{Pb}, \mathrm{Mn}, \mathrm{Cu}$, $\mathrm{Ni}$, and $\mathrm{Cr}$ were observed to be less than zero, which indicates that the lake is not polluted because of these metals. Analysis based on $95^{\text {th }}$ percentiles, the values of $\mathrm{EF}$ for As (range 107.31-276.67\%) with an average value of $274 \%$, the value of EF for Cd (range 530-590\%) with an average value of $300 \%$; the value of $\mathrm{EF}$ for $\mathrm{Fe}$ (range 828.54-934.97\%) with an average value of $907 \%$ as shown in Fig. 3b). EF calculated based on the mean values also indicate severe enrichment of $\mathrm{As}, \mathrm{Cd}$, and Fe as shown in Fig. 3a).

The findings from $\mathrm{I}_{\mathrm{geo}}$ and $\mathrm{EF}$ are in agreement that $\mathrm{As}, \mathrm{Fe}$ and $\mathrm{Cd}$ confirm that human activities in the upstream or around the lake are primarily responsible for higher concentrations of these metals in the surface sediment of Keenjhar Lake.

\section{Pollution Load Index (PLI) and Degree of Contamination $\left(C_{d}\right)$}

As shown in Table 5, the values of CF for As in the (range 2.07-3.77) showed moderate contamination at some sites and considerable contamination at other sites. $\mathrm{Fe}$ and $\mathrm{Cd}$ indicated high concentration on all sites, while $\mathrm{Pb}, \mathrm{Mn}, \mathrm{Ni}, \mathrm{Cu}$, and $\mathrm{Cr}$ at all the sampling sites were observed to be less than one, revealing low contamination. The results of CF match that of $\mathrm{I}_{\text {geo }}$ and EF.

The values of PLI were observed in the range of 0.66-0.95, with an average of 0.825 . The highest PLI values were found at location 'S2' and the lowest at location 'S10'. Although the values of PLI at all sites were found to be below one, which depicts no significant contamination, at many sampling locations it is close to one, which is, in fact, a warning of contamination.
Though in the above analysis we observed that some metals are not significantly contributing to the pollution load to the lake surface sediment, the concentrations of other metals are significantly high. Nonetheless, we observed that at all of the locations, the values of $\mathrm{C}_{\mathrm{d}}$ range between 12-24, which reflects that Keenjhar lake surface sediment has a considerable degree of pollution.

\section{Nemerow Integrated Pollution Index (Pn)}

As shown in Fig. 4, we observed that the Pn values of the studied samples ranged 6.79-7.57. The values at all locations were above 3 (the minimum threshold level of Pn), which means that the integrated pollution level exceeded the threshold level and reached a strongly polluted level. The highest value of Pn occurred at Site $\mathrm{S} 1$, and the lowest at S10. The highest value of Pn at

Table 7. Principle Component loading of heavy metals.

\begin{tabular}{|c|c|c|}
\hline Elements & PCA1 & PCA2 \\
\hline $\mathrm{Cd}$ & 0.955 & -0.053 \\
\hline $\mathrm{Fe}$ & 0.920 & -0.015 \\
\hline $\mathrm{As}$ & 0.562 & 0.122 \\
\hline $\mathrm{Cu}$ & -0.319 & 0.772 \\
\hline $\mathrm{Mn}$ & 0.133 & 0.771 \\
\hline $\mathrm{Pb}$ & 0.039 & 0.690 \\
\hline $\mathrm{Total} \mathrm{Cr}$ & 0.172 & 0.626 \\
\hline $\mathrm{Ni}$ & -0.514 & 0.615 \\
\hline Eigenvalues & 2.793 & 2.150 \\
\hline \%ototal variance & 34.912 & 26.874 \\
\hline \% cumulative variance & 34.912 & 61.786 \\
\hline
\end{tabular}


Table 8. Pearson's correlation coefficients of metals and a metalloid.

\begin{tabular}{|c|c|c|c|c|c|c|c|}
\hline & $\mathrm{As}$ & Total Cr & $\mathrm{Ni}$ & $\mathrm{Mn}$ & $\mathrm{Fe}$ & $\mathrm{Cu}$ & $\mathrm{Cd}$ \\
\hline $\mathrm{As}$ & 1.000 & & & & & & \\
\hline $\mathrm{Total} \mathrm{Cr}$ & $0.144^{*}$ & 1.000 & & & & & \\
\hline $\mathrm{Ni}$ & -0.095 & $0.239^{* *}$ & 1.000 & & & & \\
\hline $\mathrm{Mn}$ & $0.183^{* *}$ & $0.284^{* *}$ & $0.450^{* * *}$ & 1.000 & & & \\
\hline $\mathrm{Fe}$ & $0.283^{* *}$ & 0.064 & $-0.437^{* * *}$ & $0.146^{*}$ & 1.000 & & \\
\hline $\mathrm{Cu}$ & $-0.197^{* *}$ & $0.322^{* *}$ & $0.498^{* * *}$ & $0.490^{* * *}$ & $-0.232^{* *}$ & 1.000 & \\
\hline $\mathrm{Cd}$ & $0.393^{* * *}$ & 0.093 & $-0.479^{* * *}$ & 0.040 & $0.928^{* * *}$ & $-0.295^{* *}$ & 1.000 \\
\hline $\mathrm{Pb}$ & 0.002 & $0.334^{* *}$ & $0.231^{* *}$ & $0.333^{* *}$ & -0.011 & $0.499^{* * *}$ & 0.023 \\
\hline
\end{tabular}

$* * *=$ significant at $0.001 ; * *=$ significance at $0.05 ; *=$ significance at 0.1

location 1 indicates the highest pollution influx from upstream coming through KB feeder and entering the lake at its inlet. Nevertheless, the Pn values of other locations also indicate that the KB feeder is not the only source of pollution influx, but other sources of pollution are also contributing to the pollution of the lake.

\section{Potential Ecological Risk Index (PERI)}

Except for $\mathrm{Cd}$, the values of ERI as calculated for all metals and metalloid at all the sampling locations were below 40 (Table 6), which indicates low ecological risk. The values of $\mathrm{Cd}$ at all sites were in the range of 160-320, which indicates a high ecological risk. Similarly, the values of PERI as calculated for all metals and metalloid for all the sampling locations were above 150 and lower than 300, manifesting moderate ecological risk. The values of PERI were lowest at location S4 and highest at S5. Cd was the main contributor to potential ecological risk.

\section{Multivariate Analysis}

In order to analyze the association among the variables in the dataset, PCA was employed to explore the sources of heavy metals. As shown in Table 7, two principle components with eigenvalues $>1$ have been considered, and explain more than $61 \%$ of the total variance. PC1 explained about $35 \%$ of the variance with a high loading of $\mathrm{Cd}$, Fe, and As. However, PC2 explained around $26 \%$ of the variance with high loading of the remaining studied metals, including $\mathrm{Cu}$, $\mathrm{Mn}, \mathrm{Pb}, \mathrm{Cr}$, and $\mathrm{Ni}$. In some studies, the association of

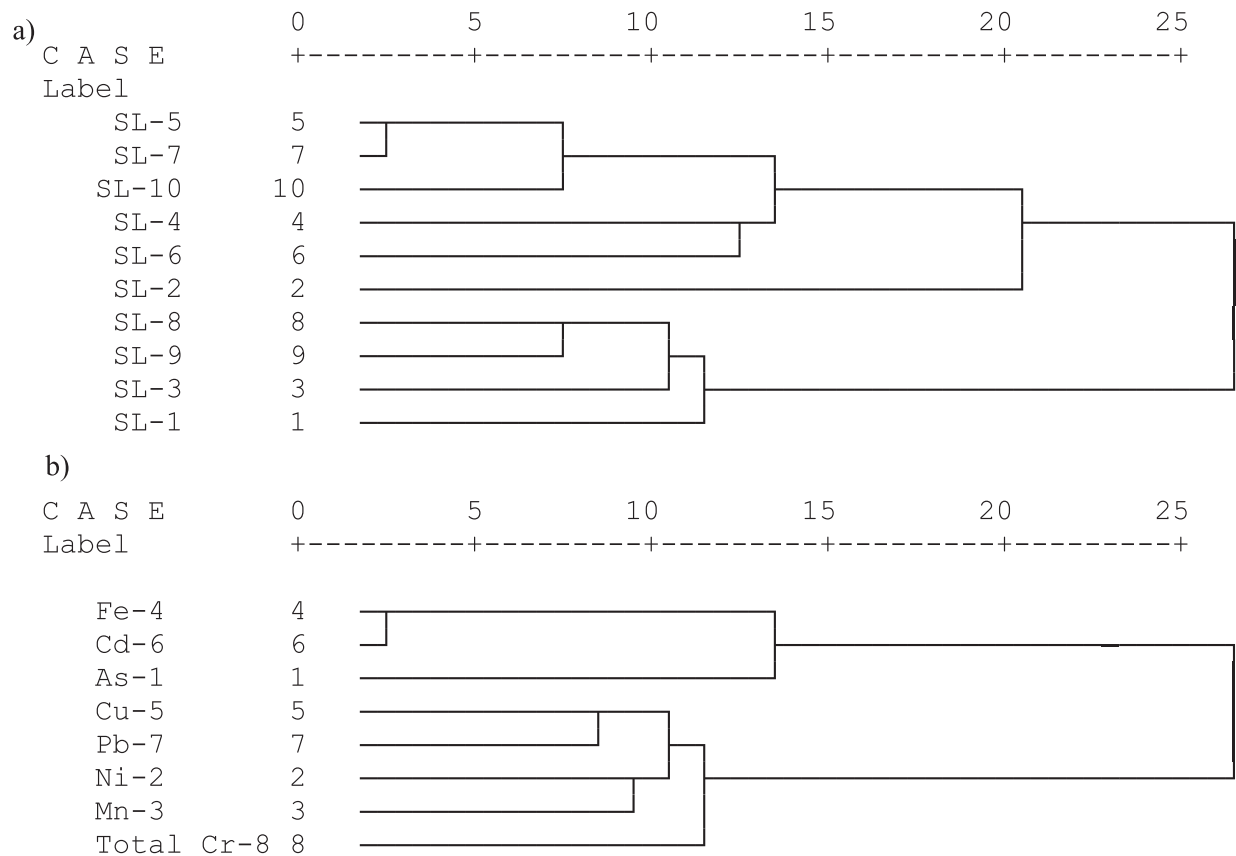

Fig. 5. Dendrogram of sampling location a) and metal concentration b) using Ward Method. 
elements with PCs has been used to distinguish natural or anthropogenic sources [30]. Therefore, the elements belonging to the first group, such as $\mathrm{As}, \mathrm{Cd}$, and $\mathrm{Fe}$, could be identified as the result of an "anthropogenic factor" due to their high EF values. On the other hand, the elements in the second group $(\mathrm{Cu}, \mathrm{Mn}, \mathrm{Pb}, \mathrm{Cr}$, and $\mathrm{Ni}$ ) are likely derived from natural sources, given their low EF value. The correlation coefficients of metals are provided in Table 8. Fig. 5 represents the sampling location relationships a) and metal-wise relationships b).

\section{Conclusions}

To investigate the level of degree of ecological risk of heavy metals and the metalloid in surface sediments of Keenjhar Lake, the concentrations of eight metals $(\mathrm{Pb}, \mathrm{Cd}, \mathrm{Cu}, \mathrm{Fe}, \mathrm{Mn}, \mathrm{Ni}$, and $\mathrm{Cr})$ and a metalloid (As) were evaluated from 10 sites on the lake. Results showed that the $95^{\text {th }}$ percentile values of $\mathrm{As}, \mathrm{Pb}, \mathrm{Cd}, \mathrm{Cu}$, $\mathrm{Mn}, \mathrm{Fe}, \mathrm{Ni}$, and $\mathrm{Cr}$ were 29.14, 7.56, 0.68, 9.03, 352.3, $56.43,10.46$, and $29.16 \mathrm{mg} / \mathrm{Kg}$ respectively. Based on the $95^{\text {th }}$ percentile, the results of EF - As (274\%), Cd $(300 \%)$ and $\mathrm{Fe}(907 \%)$ and Igeo (moderately polluted by $\mathrm{As}$ and $\mathrm{Cd}$ and moderately to highly polluted by $\mathrm{Fe}$ ) - of $\mathrm{Fe}$, As and $\mathrm{Cd}$ were mainly contributing to lake pollution, while $\mathrm{Pb}, \mathrm{Mn}, \mathrm{Cu}, \mathrm{Ni}$, and $\mathrm{Cr}$ have less contribution to lake contamination. The $\mathrm{Cd}$ shows considerable contamination (between 160-320) at all the sites, and PLI indicates no significant contamination at a few sites, but its value at some sites was near the threshold limit of 1 . The results of Pn Index (ranging $6.79-7.59$, i.e., $>3$ ) showed strongly polluted level at all sites. Cd results (between 160-320) of ERI showed that ecological risk from individual metals and the metalloid at all the sites were low, and only because of $\mathrm{Cd}$, and ERI showed high ecological risk. The values of PERI (between 150-300) at all the sampling sites indicate moderate ecological risk. The result of PCA shows that the elements belonging to the $\mathrm{PCl}$ are $\mathrm{As}, \mathrm{C}_{\mathrm{d}}$, and $\mathrm{Fe}$ could be identified as a result of anthropogenic factors due to their high EF values. On the other hand, $\mathrm{Cu}$, $\mathrm{Mn}, \mathrm{Pb}, \mathrm{Cr}$, and $\mathrm{Ni}$ are grouped in $\mathrm{PC} 2$, indicating that these elements have high correlations and therefore the sources of these elements might be the same. Since the lake is receiving contamination from several on-site and upstream economic activities, ranging agriculture, urban and industrial activities, it is difficult to establish the sources of these pollutants. Nevertheless, this study may be taken as a reference point to investigate the sources of these pollutants.

\section{Acknowledgments}

The authors of this study are grateful to the United States Agency for International Development (USAID) for funding the project "Keenjhar Lake water quality assessment and valuing ecosystems services." The
U.S.-Pakistan Center for Advanced Studies in Water (USPCAS-W), Mehran University of Engineering and Technology (MUET) Jamshoro, Sindh, Pakistan, is also recognized for providing laboratory facilities for conducting this research.

\section{Conflict of Interest}

The authors declare no conflict of interest.

\section{References}

1. GAO L., GAO B., XU D., PENG W., LU J. Multiple assessments of trace metals in sediments and their response to the water level fluctuation in the Three Gorges Reservoir, China. Science of the Total Environment, 648, 197, 2019.

2. GARNERO P.L., MONFERRAN M.V., GONZÁLEZ G.A., GRIBOFF J., DE LOS ÁNGELES B.M. Assessment of exposure to metals, As and Se in water and sediment of a freshwater reservoir and their bioaccumulation in fish species of different feeding and habitat preferences. Ecotoxicology and Environmental Safety, 163, 492, 2018.

3. KAYEMBE J.M., BOKWOKWO M.I., SIVALINGAM P., NGELINKOTO P., OTAMONGA J.P., MULAJI C.K., MUBEDI J.I., POTÉ J. Effect of untreated urban effluents on the accumulation of toxic metals in river sediments under tropical conditions: Funa River, Kinshasa, Democratic Republic of the Congo. Water and Environment Journal, 1, 2018.

4. SWARNALATHA K., NAIR A.G. Assessment of sediment quality of a tropical lake using sediment quality standards. Lakes and Reservoirs: Research and Management, 22 (1), 65, 2017.

5. JIN Z., DING S., SUN Q., GAO S., FU Z., GONG M., LIN J., WANG D., WANG Y. High resolution spatiotemporal sampling as a tool for comprehensive assessment of zinc mobility and pollution in sediments of a eutrophic lake. Journal of Hazardous Materials, 364, 182, 2019.

6. LARIBI A., MOUHOUCHE B., BENAYAD T., DEHNOUN Z. Contamination assessment and the risk associated with the accumulation of trace metals in sediments of the Mitidja plain, Algeria. Environmental Progress and Sustainable Energy, 36 (6), 1650, 2017.

7. HASAN M., KAUSAR D., AKHTER G., SHAH M.H. Evaluation of the mobility and pollution index of selected essential/toxic metals in paddy soil by sequential extraction method. Ecotoxicology and Environmental Safety, 147, 283, 2018.

8. ZHU H., BING H., WU Y., ZHOU J., SUN H., WANG J., WANG X. The spatial and vertical distribution of heavy metal contamination in sediments of the Three Gorges Reservoir determined by anti-seasonal flow regulation. Science of the Total Environment, 664, 79, 2019.

9. IMRAN U., ULLAH A., SHAIKH K., MEHMOOD R., SAEED M. Health risk assessment of the exposure of heavy metal contamination in surface water of lower Sindh, Pakistan. SN Applied Sciences, 1 (6), 1, 2019.

10. ALAHABADI A., MALVANDI H. Contamination and ecological risk assessment of heavy metals and metalloids in surface sediments of the Tajan River, Iran. Marine Pollution Bulletin, 133, 741, 2018. 
11. FENG Y., BAO Q., XIAO X., LIN M. Geo-accumulation vector model for evaluating the heavy metal pollution in the sediments of Western Dongting Lake. Journal of Hydrology, 573, 40, 2019.

12. REN M., DING S., FU Z., YANG L., TANG W., TSANG D.C. W., WANG D., WANG Y. Seasonal antimony pollution caused by high mobility of antimony in sediments: In situ evidence and mechanical interpretation. Journal of Hazardous Materials, 367, 427, 2019.

13. ENUNEKU A., OMORUYI O., TONGO I., OGBOMIDA E., OGBEIDE O., EZEMONYE L. Evaluating the potential health risks of heavy metal pollution in sediment and selected benthic fauna of Benin River, Southern Nigeria. Applied Water Science, 8 (8), 2018.

14. ZHAO X., GAO B., XU D., GAO L., YIN S. Heavy metal pollution in sediments of the largest reservoir (Three Gorges Reservoir) in China: a review. Environmental Science and Pollution Research, 24 (26), 20844, 2017.

15. OZSEKER K., ERUZ C. Pollution Assessment of Toxic Metals in Representative Limnetic Ecosystem Sediments in the Southeastern Black Sea, Turkey. Clean - Soil, Air, Water, 45 (10), 2017.

16. MASSAQUOI L.D., MA H., LIU X.H., HAN P.Y., ZUO S.M., HUA Z.X., LIU D. W. Heavy metal accumulation in soils, plants, and hair samples: an assessment of heavy metal exposure risks from the consumption of vegetables grown on soils previously irrigated with wastewater. Environmental Science and Pollution Research, 22 (23), 18456, 2015

17. ZHUANG W., YING S.C., FRIE A.L., WANG Q., SONG J., LIU Y., CHEN Q., LAI X. Distribution, pollution status, and source apportionment of trace metals in lake sediments under the influence of the South-to-North Water Transfer Project, China. Science of the Total Environment, 671, 108, 2019.

18. WWF (World Wildlife Fund). Detailed ecological assessment of fauna, including limnology studies at Keenjhar Lake. World Wide Fund Pakistan. Retrieved November 17, 2018, from http://foreverindus.org/pdf/sites/ Keenjhar_ecological2008.pdf, 2008.

19. KORAI A.L., SAHATO G.A., KAZI T.G., LASHARI K.H. Lead concentrations in fresh water, muscle, gill and liver of Catla catla (Hamilton) from Keenjhar Lake. Pakistan Journal of Analytical and Environmental Chemistry, 9 (1), 11, 2008.

20. NERGIS Y., YAHA S.M., RAHMAN A.U., SIDDIQUI S.A. Appraisal of water quality of Keenjhar Lake by using statistical techniques and water quality index. Asian Journal of Biochemical and Pharmaceutical Research, 4 (3), 19, 2013.

21. AKBAR G., KHATOON S., IMRAN M., RIZWAN N., KHAN M.Z., ISLAM S. Floristic and Phyto-Sociological Assessment of Vegetation of Keenjhar Lake and Surrounding Area (Thatta, Sindh), Pakistan. International Journal of Biology and Biotechnology, 7 (3), 197, 2010.

22. BAIG L.A., SHAIKH S., POLKOWSKI M., ALI S.K., JAMALI S., MAZHARULLAH L., SOOMRO M., KUMARI B., MEMON S., MAHESHWAR G., ARIF S. Violence against health care providers: A mixed-methods study from Karachi, Pakistan. The Journal of Emergency Medicine, 54 (4), 558, 2018.

23. MANGAN T., BROUWER R., DAS LOHANO H., NANGRAJ G.M. Estimating the recreational value of Pakistan's largest freshwater lake to support sustainable tourism management using a travel cost model. Journal of Sustainable Tourism, 21 (3), 473, 2013.
24. US EPA (U.S. Environmental Protection Agency). Acid digestion of sediments, sludges, and soils. Method $3050 B$. Retrieved April 8, 2018, from https:/www.epa.gov/sites/ production/files/2015-06/documents/epa-3050b.pdf, 1996.

25. IQBAL J., SALEEM M., SHAH M.H. Spatial distribution, environmental assessment and source identification of metals content in surface sediments of freshwater reservoir, Pakistan. Chemie der Erde - Geochemistry, 76 (1), 171, 2016.

26. RICE E.W., BAIRD R.B., EATON A.D., CLESCERI L.S. Standard Methods for the Examination of Water and Wastewater. American Public Health Association, American Water Works Association, Water Environment Federation (22 ${ }^{\text {nd }}$ ed.). American Public Health Association, American Water Works Association, Water Environment Federation. 2012.

27. SHAH M.T., ARA J., MUHAMMAD S., KHAN S., TARIQ S. Health risk assessment via surface water and sub-surface water consumption in the mafic and ultramafic terrain, Mohmand agency, northern Pakistan. Journal of Geochemical Exploration, 118, 60, 2012.

28. CHENG Z., MAN Y.B., NIE X.P., WONG M.H. Trophic relationships and health risk assessments of trace metals in the aquaculture pond ecosystem of Pearl River Delta, China. Chemosphere, 90 (7), 2142, 2013.

29. HOU D., HE J., LÜ C., REN L., FAN Q., WANG J., XIE Z. Distribution characteristics and potential ecological risk assessment of heavy metals $(\mathrm{Cu}, \mathrm{Pb}, \mathrm{Zn}, \mathrm{Cd})$ in water and sediments from Lake Dalinouer, China. Ecotoxicology and Environmental Safety, 93, 135, 2013.

30. WANG J., LIU R., ZHANG P., YU W., SHEN Z., FENG C. Spatial variation, environmental assessment and source identification of heavy metals in sediments of the Yangtze River Estuary. Marine Pollution Bulletin, 87 (1), 364, 2014v

31. LUO W., LU Y., ZHANG Y., FU W., WANG B., JIAO W., WANG G., TONG S., GIESY J.P. Watershed-scale assessment of arsenic and metal contamination in the surface soils surrounding Miyun Reservoir, Beijing, China. Journal of Environmental Management, 91 (12), 2599, 2010.

32. ZHU X., JI H., CHEN Y., QIAO M., TANG L. Assessment and sources of heavy metals in surface sediments of Miyun Reservoir, Beijing. Environmental Monitoring and Assessment, 185 (7), 6049, 2013.

33. REHMAN I. UR, ISHAQ M., ALI L., KHAN S., AHMAD I., DIN I.U., ULLAH H. Enrichment, spatial distribution of potential ecological and human health risk assessment via toxic metals in soil and surface water ingestion in the vicinity of Sewakht mines, district Chitral, Northern Pakistan. Ecotoxicology and Environmental Safety, 154, 127, 2018.

34. GHALENO O.R., SAYADI M.H., REZAEI M.R. Potential ecological risk assessment of heavy metals in sediments of water reservoir case study: Chah Nimeh of Sistan. International Academy of Ecology and Environmental Sciences, 5 (4), 89, 2015.

35. KOWALSKA J.B., MAZUREK R., GĄSIOREK M., ZALESKI T. Pollution indices as useful tools for the comprehensive evaluation of the degree of soil contamination - A review. Environmental Geochemistry and Health, 40 (6), 2395, 2018.

36. IQBAL J., SHAH M.H. Occurrence, risk assessment, and source apportionment of heavy metals in surface sediments from Khanpur Lake, Pakistan. Journal of Analytical Science and Technology, 5 (1), 1, 2014. 
37. TUREKIAN K.K., WEDEPOHL K.H. Distribution of the elements in some major units of the earth's crust. Geological Society of America Bulletin, 72, 175, 1961.

38. ABUBAKAR U.S., ZULKIFLI S.Z., ISMAIL A. Heavy metals bioavailability and pollution indices evaluation in the mangrove surface sediment of Sungai Puloh, Malaysia. Environmental Earth Sciences, 77, 225, 2018.

39. KARAK T., BORA K., PAUL R.K., DAS S., KHARE P., DUTTA A.K., BORUAH R.K. Paradigm shift of contamination risk of six heavy metals in tea (Camellia sinensis L.) growing soil: A new approach influenced by inorganic and organic amendments. Journal of Hazardous Materials, 338, 250, 2017.

40. WAN L., XU L., FU Y. Contamination and risk assessment of heavy metals in lake bed sediment of a large lake scenic area in china. International Journal of Environmental Research and Public Health, 13 (7), 2016.

41. WOJCIECHOWSKA E., NAWROT N., WALKUSZMIOTK J., MATEJ-ŁUKOWICZ K., PAZDRO K. Heavy metals in sediments of urban streams: Contamination and health risk assessment of influencing factors. Sustainability (Switzerland), 11 (3), 5, 2019.

42. TOMLINSON D., WILSON J., HARRIS C., JEFFREY D. Problems in the assessment of heavy-metal levels in estuaries and the formation of a pollution index. Helgolander Meeresunters, 33, 566, 1980.

43. HAKANSON L. An ecological risk index for aquatic pollution control. A sedimentological approach. Water Research, 14, 975, 1980.

44. CHEN H., TENG Y., LU S., WANG Y., WANG J. Contamination features and health risk of soil heavy metals in China. Science of the Total Environment, 512-513, 143, 2015.

45. HUANG Y., CHEN Q., DENG M., JAPENGA J., LI T., YANG X., HE Z. Heavy metal pollution and health risk assessment of agricultural soils in a typical periurban area in southeast China. Journal of Environmental Management, 207, 159, 2018.
46. SHARIFINIA M., TAHERIZADEH M., NAMIN J.I., KAMRANI E. Ecological risk assessment of trace metals in the surface sediments of the Persian Gulf and Gulf of Oman: Evidence from subtropical estuaries of the Iranian coastal waters. Chemosphere, 191, 485, 2018.

47. WANG L.F., YANG L.Y., KONG L.H., LI S., ZHU J.R., WANG Y.Q. Spatial distribution, source identification and pollution assessment of metal content in the surface sediments of Nansi Lake, China. Journal of Geochemical Exploration, 140, 87, 2014.

48. WU S., PENG S., ZHANG X., WU D., LUO W., ZHANG T., ZHUO S., YANG G., WAN H., WU L. Levels and health risk assessments of heavy metals in urban soils in Dongguan, China. Journal of Geochemical Exploration, 148, 71, 2015.

49. IQBAL J., TIRMIZI S.A., SHAH M.H. Statistical apportionment and risk assessment of selected metals in sediments from Rawal Lake (Pakistan). Environmental Monitoring and Assessment, 185 (1), 729, 2013.

50. DUMAN F., AKSOY A., DEMIREZEN D. Seasonal variability of heavy metals in surface sediment of Lake Sapanca, Turkey. Environmental Monitoring and Assessment, 133, 277, 2007.

51. SALEEM M., IQBAL J., SHAH M.H. Study of seasonal variations and risk assessment of selected metals in sediments from Mangla Lake, Pakistan. Journal of Geochemical Exploration, 125, 144, 2013.

52. BAI J., CUI B., CHEN B., ZHANG K., DENG W., GAO H., XIAO R. Spatial distribution and ecological risk assessment of heavy metals in surface sediments from a typical plateau lake wetland, China. Ecological Modelling, 222 (2), 301, 2011.

53. SKORDAS K., KELEPERTZIS E., KOSMIDIS D., PANAGIOTAKI P., VAFIDIS D. Assessment of nutrients and heavy metals in the surface sediments of the artificially lake water reservoir Karla, Thessaly, Greece. Environmental Earth Sciences, 73 (8), 4483, 2015. 